\title{
\begin{tabular}{l|l} 
Mitraries & DSpace@MIT
\end{tabular}
}

\author{
MIT Open Access Articles
}

\section{Invasive and Introduced Plants and Animals: Human Perceptions, Attitudes and Approaches to Management (Book review)}

The MIT Faculty has made this article openly available. Please share how this access benefits you. Your story matters.

Citation: Ritvo, Harriet. "Book Review of Invasive and Introduced Plants and Animals: Human Perceptions, Attitudes and Approaches to Management." Edited by lan D. Rotherham and Robert A. Lambert. Washington, DC: Earthscan, 2011. xvi + 375 pp. Illustrations, maps, tables, references, and index. Environmental History (2012) 17(3): 669-671.

As Published: http://dx.doi.org/10.1093/envhis/ems074

Publisher: Oxford University Press

Persistent URL: http://hdl.handle.net/1721.1/72171

Version: Author's final manuscript: final author's manuscript post peer review, without publisher's formatting or copy editing

Terms of use: Creative Commons Attribution-Noncommercial-Share Alike 3.0 
Invasive and Introduced Plants and Animals: Human Perceptions, Attitudes and Approaches to Management. Edited by Ian D. Rotherham and Robert A. Lambert. Washington DC: Earthscan, 2011. xvi + 375 pp. Illustrations, maps, tables, references, and index. Cloth \$65.00.

The essays collected in this fascinating compendium are very diverse. They deal with most continents and several time periods. Their authors represent the fields of history, biology, economics, forestry, anthropology, sociology, geography, philosophy, and tourism studies. Their distinctive disciplinary perspectives are illuminating, but their convergences may be even more so. Whether they focus on plants or animals, or on South Africa or New Zealand or Britain, and whether they analyze past introductions or propose strategies for future management of problem species, nearly all the essays engage issues of language and classification.

Matthew K. Chew's contribution foregrounds such concerns, offering a historical survey of "anekeitaxonomy,” which he defines as the classification of species according to whether or not they are native (and how native they are). But taxonomic questions also shape the more grounded discussions that constitute the bulk of the volume. Even deciding whether a species is native is a judgment call, depending, among other things, on how far back the judge is inclined to look. Thus, Chris Smout very usefully distinguishes between "archaeophytes” and “neophytes.” Does the mere fact of previous occupation mean that reoccupation is to be desired or tolerated or encouraged (and by whom)? With regard to recent British experience, Robert A. Lambert discusses how raptors have “(re)wilded” the skies, and Martin Goulding discusses the appropriation of woodlands by wild boars. Since the founders of the boar population were necessarily imported from continental Europe, their indigeneity is subject to challenge by purists. And since they escaped from game farms and interbreed happily with domestic pigs if 
they encounter them, they broach another vexed taxonomic distinction—-between the domesticated and the wild.

A tension that runs through the volume pits scientific expertise against sentiment, popular or otherwise. As Simon Pooley demonstrates in his account of the early twentieth-century attempts to protect the fynbos flora of South Africa, expert opinion about the effect of introduced and invasive species, and therefore about what, if anything, to do about them has been as volatile as the ranges of the species themselves—and the opposition between expertise and sentiment is far from absolute. Nevertheless the biologist Daniel Simberloff firmly defends the current expert consensus that introduced species are a problem to be dealt with, explicitly countering those who, like the philosopher Mark Sagoff, use words like "xenophobic" to characterize his position.

Of course, "xenophobia" is not the only highly charged term to figure repeatedly in this volume. "Native,” “alien,” and "invasive,” although often used as technical (if imprecise) labels, also carry strong emotional overtones. And, as Simberloff and some other contributors more sympathetic to non-expert perspectives would agree, the treatment of introduced species varies greatly, depending on how much the human inhabitants of their new habitat like them. In Britain, on the whole, the larger and furrier, the better, although, as Peter Coates points out in his engaging essay on squirrels, fur does not guarantee immunity from persecution. Because of its provenance, the North American gray squirrel, which has flourished dramatically in its adopted home, has become the object of free-floating anti-Americanism. It is perceived to have displaced the indigenous red squirrel, beloved since the days of Beatrice Potter as Squirrel Nutkin. 
More practical considerations also influence the extent to which conservation managers are empowered to eradicate introduced species. Some, such as the rhododendron, discussed by Ian D. Rotherrham, and even Japanese knotweed, discussed by John Bailey, are (or were originally) appreciated for their aesthetic value. Pierre Binggeli points out that in tropical Africa, local residents derive economic benefits from many plants that Western experts would like to extirpate. According to Hazel Petrie, within a few decades of its introduction to New Zealand in the nineteenth century, the horse had become firmly integrated into Maori law and religion.

Although historians are likely to be most interested in what has already happened, this volume looks towards the future as well as the past; its subtitle calls attention to the practical implications of the research it distills. As the editors provide a clear and comprehensive overview of the intellectual and practical problems inherent in their topic in the introduction, so they conclude with sensible advice for "the way ahead." In particular they urge that only "problem" species (rather than any species that can be labeled "alien”) be targeted for control, and that policy decisions should be based on the views of affected human communities, as well as on the findings of experts, and that those experts should include humanists as well as scientists.

\section{Harriet Ritvo}

Massachusetts Institute of Technology ritvo@MIT.EDU 